\title{
РОЛЬ ЗЕМСТВ У РОЗВИТКУ ТРУДОВОГО НАВЧАННЯ В КАТЕРИНОСЛАВСЬКІЙ ГУБЕРНІЇ (КІНЕЦЬ ХІХ - ПОЧАТОК ХХ СТОЛІТТЯ)
}

У статті на основі аналізу архівних джерел та краєзнавчої літератури розглянуто діяльність земств у галузі народної освіти та розвитку трудового навчання в Катеринославській губернії.

Ключові слова: земство, народна освіта, земська школа, трудове навчання, реміснича освіта, ручна праця.

В статье на основе анализа архивных источников и краеведческой литературы рассматривается деятельность земств Екатеринославской губернии в отрасли народного образования и развития трудового обучения.

Ключевые слова: земство, народное образование, земская икола, трудовое обучение, ремесленное образование, ручной mpyд.

The article examines the activities of zemstvo Ekaterinoslav province in the sectors of education and the development of labor training.

Key words: zemstvo, national education, zemstvo's school, labor training, handicraft education, manual labor.

У кінці XIX - на початку XX століття суспільно-економічні трансформації зумовили зміну підходів до системи освіти, оскільки більшою мірою потребували компетентних фахівців для різних галузей промисловості та вправних умілих робітників. Задля цього створювалися реальні училища, а до навчальних планів і програм початкових та середніх загальноосвітніх закладів упроваджувалося трудове навчання. Проблеми школи, освіти, підготовки молоді до життя стали програмними в діяльності земських органів самоврядування.

Історіографія земств за своїми масштабами та глибиною досліджень посідає визначне місце в історії Росії й України. Широка палітра діяльності земств, їх роль як інституту управління викликали в сучасників, а пізніше в дослідників, значний інтерес, який не згасає й сьогодні. Слід відзначити монографію А. Лохматової [4], яка дає наочне уявлення про успіхи органів місцевого самоврядування в дореволюційній Росії, їх значення в економічному та культурному розвитку Катеринославського краю. У працях А. Голуб [2], І. Кочергіна [3], Л. Рябовол [11] та інших висвітлено діяльність земського самоврядування та його роль у розвитку народної освіти.

Однак проблема трудового навчання недостатньо розглянута в історико-педагогічній літературі, тому потребує спеціального дослідження 3 акцентом на конкретні види діяльності земств Катеринославської губернії у галузі ремісничої освіти.

Mema cmammi - дослідити діяльність земських установ у галузі народної освіти та розвитку трудового навчання в Катеринославській губернії.

У другій половині XIX - на початку XX століття значне місце в суспільно-політичному житті країни посідали земства - органи місцевого самоврядування, які утворилися 1 січня 1864 р. 3 гідно 3 «Положенням про повітові та земські установи». 3 квітня 1865 р. земства почали функціонувати в Херсонській губернії, з вересня - у Полтавській та Чернігівській, а з жовтня - у Харківській губернії. На Катеринославщині «Положення» земської реформи почали втілюватися в життя в листопаді 1865 р., коли в кількох повітах відбулися вибори гласних повітових земських зібрань. Перші сесії земств відкрилися у Верхньодніпровському, Катеринославському, Новомосковському i Павлоградському повітах у лютому 1866 р. На них були обрані представники до губернського земства. Тоді ж були створені повітові земські управи [3, с. 10].

Окрім питань щодо влаштування рівня життя громадян, земські збори й управи опікувалися $\mathrm{i}$ розвитком народної освіти. Для правильного ведення справи народної освіти в земствах мала місце система розподілу повноважень. Освітню справу в губернії організовували та проводили земські повітові та губернські збори зі своїми підготовчими комісіями, постійні комісії з народної освіти, земські управи, завідуючі шкільною справою, відділи народної освіти, які існували при управах, голова училищної ради, його помічники, члени ради від земств, інші органи та окремі посадові особи $[11$, с. 29].

Зміст діяльності земських установ полягав у відкритті шкіл, бібліотек, організації освітніх заходів для дорослих тощо. Передовсім земці піклувалися про матеріальну забезпеченість шкіл. Кращі представники училищних рад від земств дбали про будівництво шкільних приміщень, про забезпечення учнів шкіл підручниками, посібниками, письмовим приладдям. Задля трудової підготовки учнів, запроваджували у школах уроки ручної праці, створювали шкільні майстерні, пришкільні земельні ділянки і сади.

Із перших років функціонування земських шкіл головною турботою земства було викликати інтерес селян до здобуття освіти. «Якщо земство досягне цього результату, то справу народної освіти - цього важливого чинника добробуту громадського ладу - можна вважати забезпеченою» [8, с. 266]. 
3 освіченістю населення земство тісно пов'язувало його економічний побут та добробут. Селянські діти, на думку земства, одержавши в школі відомості про грунт, клімат, способи обробки землі, культури рослин, домашню худобу, догляд за нею, увійдуть в життя підготовленими і на будьякій ниві своєї діяльності будуть застосовувати набуті в школі знання [8, с. 265-266].

Повільне поширення земських шкіл в кінці XIX століття зумовлювалося негативним ставленням селян до школи, крім цього, діти 12-14 років були потрібні вдома у якості помічника. Тому багато учнів по завершенні першого року навчання залишало школу. Учителі земських шкіл прагнули переконати батьків учнів у необхідності освіти і неприпустимості відривання дітей від навчання. Завдяки пояснювальній роботі з-поміж батьків кількість школярів, які передчасно закінчували навчання, поступово зменшувалася.

Велику увагу земства Катеринославської губернії приділяли ролі самого вчителя народної школи. Щоб сформувати позитивне ставлення селянства до школи, вчитель повинен був, по-перше, зацікавити дітей навчанням; по-друге - налагоджувати стосунки з батьками. У більшості випадків від стосунків між учителем та батьками залежало, чи будуть діти ходити до школи.

Задля залучення дітей селян до школи земства Катеринославщини використовували різні заохочення. Наприклад, повітове Маріупольське земство забезпечувало учнів народних шкіл взуттям та одягом. Земські установи Новомосковського повіту протягом зимового періоду надавали допомогу продуктами харчування сім'ям найбідніших учнів [7, с. 136-137]. Окрім матеріальної допомоги, земські органи самоврядування повинні були довести батькам необхідність освіти, тому в народних школах влаштовувалися дні відкритих занять, коли всі, хто бажав, спостерігали за навчальновиховним процесом в училищах.

Поступово негативне ставлення селянства до народної освіти у Катеринославській губернії переродилося у бажання отримати освіту. Училищна рада, доповідаючи Олександрівським повітовим зборам, зазначала, що «був час і не так давно, коли наші школи рахували учнів десятками, коли дітей 3 труднощами притягували на навчання; тепер школи буквально переповнені сотнями дітей і сотні ж не мають можливості навчатися за браком місць» [9, с. 195].

Про темпи розвитку народної освіти свідчать асигнування, які щорічно збільшувалися та школи, які щорічно відкривалися. У Катеринославській губернії в 1877 році земських шкіл нараховувалося 253, а в 1903 їх кількість зросла до 454.

Значною була діяльність губернського земства 3 підготовки дітей до самостійного (дорослого) життя. Органи самоврядування сприяли впровадженню ручної праці в школах та їх методичному забезпеченні. За оцінками сучасників, саме земства були найбільш зацікавленими в розширенні навчання 3 ручної праці; земські органи відкривали майстерні при школах, допомагали в їх оснащенні, асигнували кошти на трудове навчання. Земства дбали про навчання ремеслам, які задовольняли б потреби господарства, готували вправних робітників, а також спонукали до розвитку кустарно-художніх промислів.

Питання щодо сприяння розповсюдженню ремісничих знань поміж населення порушувалося на губернських земських зборах у 1869 році. Тоді ж асигновано 24 тис. крб. (по 3 тис. на кожний повіт) із тим, щоб на надані кошти повітові земства почали відкривати ремісничі школи. Однак, як повідомили повітові управи, вони не змогли масово розпочати їх організації, бо не було вчителів ремісничого навчання. Можна визначити й ще одну причину, з якої повітові земства не поспішали відкривати ремісничі школи - їхня принципова незгода поєднувати загальноосвітнє навчання 3 професійним [4, с. $145-146]$.

Власну позицію з цього питання обгрунтував барон М. Корф, який уважав, що грамоти необхідно навчати малих дітей, ремеслу - тих, хто вже, зміцнів, відтак до ремісничої школи могли вступати ті, хто вже скінчив народну школу й одержав грунтовну початкову освіту [10, с. 21].

Проте, віддаючи належне М. Корфу як засновнику земської школи, гласний Катеринославського повіту Я. Савельєв розходився з ним у питанні ставлення до ремісничої освіти. Він уважав, що для народу «зайві казки, надмірна ідеологія шкідлива», що йому у першу чергу «потрібна елементарна освіта, яка принесла б йому очевидну і відчутну користь для добування шматка хліба». Саме таку освіту можна було, на думку Я. Савельєва, одержати у ремісничих школах, справу організації і утримання яких мало б взяти на себе земство [2, с. 17].

У 1883 році на території Олександрівського повіту на кошти повітового земства відкрито земську двокласну школу з п'ятирічним терміном навчання. За зразком Олександрівського повітового земства по всій Катеринославській губернії зусиллями повітових земських установ та сільських громад протягом 1885-1913 рр. почали функціонувати ще вісім двокласних земських училищ. Програма навчання у двокласній земській школі значно розширилася, порівняно з однокласною, за рахунок уведення до шкільного розкладу геометрії, історії Росії або рідного краю, а також ремісничого відділення (ручна столярна або слюсарна праця) [1].

У ремісничому відділенні школярі могли оволодіти навичками з теслярства або металознавства. Програму ремісничого відділення складено таким чином, що за п’ять років навчання школяр набував достатній обсяг умінь і навичок, необхідних йому для ведення домашнього господарства, а також можливості відкриття власної справи. 
Катеринославською губернською училищно-педагогічною радою в 1889 році розроблено єдину для всіх губернських двокласних земських шкіл навчальну програму з ручної праці [5, с. 23]. Згідно 3 нею школярі перших трьох років навчання вивчали властивості матеріалів та виготовляли найпростіші вироби 3 дерева чи металу: свистки, ляльки, прості елементи домової геометричної різьби по дереву, чеканка. Із кожним роком ця навчальна програма дедалі ускладнювалася. Упродовж четвертого та п'ятого років навчання школярі працювали над виготовленням господарського приладдя, меблів, сільськогосподарських приладів (плуг, соха) та власне нових робочих інструментів для школи та для себе [5, с. 21].

Для професійної підготовки дітей земства організовували різноманітні гуртки садівництва, городництва, бджолярства. У 1894 р. такі гуртки діяли при 263 народних училищах губернії [6, с. 89].

Отже, можна зробити висновок, що головне завдання в галузі трудового навчання земства вбачали в тому, щоб виховати в школярів любові до праці, ознайомити 3 основами промислового й сільськогосподарського виробництва, сформувати певні трудові вміння і навички, підготувати дітей до майбутнього трудового життя. Подальше дослідження у цьому напрямі вбачаємо у вивченні організації трудового навчання в земських школах Катеринославської губернії.

\section{Література}

1. Білецький О. П. Розвиток народної освіти у Катеринославській губернії (друга половина XIX - початок XX ст.) : дис. ... канд. пед. наук : 13.00 .01 / Білецький Олексій Павлович. - Луганськ, 2009. - 193 с. 2. Голуб А. «Виконуючи обов'язок по чистій совісті...» Штрихи до портрета діячів Катеринославського земства / А. Голуб, А. Лохматова // Борисфен. - 1996. - № 2 (56). - С. 16-17. 3. Кочергін І. О. Земське самоврядування Катеринославщини (персонологічний вимір) : [монографія] / І. О. Кочергін. - Дніпропетровськ : Герда, 2011. 216 с. 4. Лохматова А. І. Катеринославське земство / А. І. Лохматова. - Запоріжжя : РА «Тандем-У», 1999. 200 с. 5. Освіта Украйни. Інформаційно-аналітичний огляд / [за заг. ред. В. Г. Кременя]. - К. : ЗАТ «НІЧЛАВА», 2001. - 224 с. 6. Отчет Екатеринославской губернской земской управы за 1894. - Екатеринослав, 1895. 7. Отчет о деятельности Екатеринославской губернской земской управы по народному просвещению за 1897-1902 гг. - Екатеринослав : тип. Л. М. Ротенберга, 1903. - 451 с. 8. Постановления Х-го очередного Верхнеднепровского уездного земского собрания с 17 по 25 сентября 1875 г. С приложениями. Екатеринослав, 1876. - С. 266. 9. Протоколы Александровского уездного земского собрания очередной сессии 1880 г. С приложениями. - Екатеринослав, 1880. 10. Протоколы Александровского уездного земского собрания очередной сессии с 26 сентября по 3 октября 1870 г. - Екатеринослав, 1871. 11. Рябовол Л. Т. Розвиток земської освіти в Херсонській губернії (друга половина XIX - початок XX століття) : дис ... канд. пед. наук: 13.00.01 / Рябовол Лілія Тарасівна. - Кіровоград, 2000. - 190 с. 